\title{
The Power of Social and Political Networking for Recruitment and Promotion for Strategic Positions: A Gender Perspective on Work Relations at Workplaces
}

\author{
Dewan Mahboob Hossain ${ }^{1} \&$ Rohaiza Rokis ${ }^{2}$ \\ ${ }^{1}$ Department of Accounting and Information Systems, University of Dhaka, Bangladesh \\ ${ }^{2}$ Department of Sociology and Anthropology, International Islamic University Malaysia, Malaysia \\ Correspondence: Rohaiza Rokis, Department of Sociology and Anthropology, International Islamic University \\ Malaysia, P.O. Box 10, 50728 Kuala Lumpur, Malaysia. Tel: 60-36-196-6109. E-mail: rohaiza@iium.edu.my
}

\author{
Received: May 30, 2014 Accepted: November 18, 2014 Online Published: April 2, 2015 \\ doi:10.5539/ass.v11n9p11 URL: http://dx.doi.org/10.5539/ass.v11n9p11
}

\begin{abstract}
Gender issues at the workplaces receive immense importance from the researchers all over the world. This study emphasizes on the core questions: how men and women maintain networks in the organizations and whether their networking strategies are different from each other. Most of the studies on this issue conducted so far are mainly based on the developed economic-based nations. This particular study however looks into this issue in the context of a developing economy of Bangladesh. By taking an old, well-reputed and large public University as a case, this study concludes that men and women have different networking strategies. Women's networks mainly revolve around women. Moreover, women are not that much interested in establishing and maintaining networks like men in the workplaces. Rather, women remain more concerned with their family affairs. These situations apparently do not directly beneficial to women on a whole. Working women are deprived from recruitment, promotion and obtaining strategic positions at the workplaces. Men, on the other hand, due to their solid and significant social networking manage to maintain positive working avenues and therefore secure their positions further.
\end{abstract}

Keywords: gender, networking, politics, promotion, recruitment, workplace

\section{Introduction}

This article is related to how employees of different genders maintain networks in the workplaces. Though gender issues in the workplaces are not new areas of study anymore, most of the studies concentrated mainly on the developed economies. This study demands a novelty as this is a case study on a workplace of the education sector of a developing economy.

\section{Background of the Study}

Kessler and McKenna (1978, p. 7) define gender as the 'psychological, social, and cultural aspects of maleness and femaleness'. Gender is perceived as the socially defined difference basing on the biological dissimilarity between the sexes (Marchbank \& Letherby, 2007). According to Ferrante (2011, p. 269): “Gender is the socially created and learned distinctions that specify the ideal physical, behavioral, and mental and emotional traits characteristic of males and females". Gender remained as a significant issue of interest among the researchers worldwide. Wharton (2005, pp. 9-10) mentioned about three reasons for which the issue of gender should be studied. Firstly, gender 'shapes the identities and behavioral dispositions' of the people in the world (Wharton, 2005 , p. 9). Secondly, gender shapes social interaction. Thirdly, gender constitutes social institution by setting some rules in the different areas of social life. That means, there are differences in the patterns of behavior and interaction between the two genders. The expectations of the society from the people of different genders are also different. That is why, in different aspects of our lives, in many cases, the people of different genders behave and interact differently in order to meet the differentiated social expectations.

These days, work and workplaces influence our life and lifestyle in a significant manner. For many years, most of the societies in the world maintained a gendered division of labor. Rosaldo (1974) highlighted that in almost every society, men work in the public sphere and women remain in the domestic sphere. Similar comments were 
found in Vogel (1983), who identified that a division of labor exists in capitalistic society, which ultimately causes the inequality between sexes. A capitalist society requires production and reproduction. It needs necessary labor for production and surplus labor for generating profit. Men meet the demand for labor by working outside and women perform the household works and biological reproduction of working-class offspring. Though this division of labor can still be seen in many parts of the world, in most of the societies, these days, women are coming out of the home and joining the workforces.

Women's issue in the workplaces is a well-researched area. Over the years, researchers in the different parts of the world have worked extensively on the various aspects of women's work life. Most of these researches concentrated on giving a comparative picture of men's and women's status in the workplace. Gender inequality in the workplaces was researched from many different angles.

Some of the researchers have worked on the financial issues. It was highlighted in many empirical investigations that men get better financial benefits in the organizations in comparison to women (Henslin, 2006; Haralombos \& Holborn, 2008; Hakim, 1996; Heath, 1981; Lauer \& Lauer, 2006; Solovic, 2001). It was seen that women generally get employed in the less paid jobs in comparison to men. It was also seen that women are facing discrimination in case of recruitment and promotion (Hunt, 1975; Brown, 1976; Ramsay \& Parker, 1992; Knights \& Morgan, 1990; Solovic, 2001). Bradley (1999, p. 82) mentioned that 'the structures of gendered power' support the dominance of men. Some researchers investigated whether women face any hindrances in getting the strategic positions in the organizations (Kendall, 2004; Crompton, 1997; Giscombe, 2007). It was found that there is a "glass ceiling" in the organization for women. It is hard for them to reach the top positions of the organizations. Most of the top positions of the organizations are for the men. Other than all these, researchers also highlighted women's strategies to maintain a balance between their works and their families (Jacobs \& Schain, 2009; Hakim, 1996; Hussain, 2008; Rohaiza; 2009; Hoscschild, 2003; Haas, 2005). Study results convey the fact that women face difficulties in making a balance between their work and family life.

It can be said from this discussion that in many ways, workplaces are dominated by men. Women get discriminated in various aspects of their job life. The experiences of men and women in the workplaces are different. This particular article also focuses on whether the networking capabilities and strategies differ between men and women. The study is based on the social network theory.

The next section of this article highlights the objectives and the methodology of the study. Then the theoretical framework of this article is described. After that a brief description of the case is presented. Then the findings and analysis of the study are given.

\section{Objectives and Methodology of the Study}

This study is a case study on the workplace of a higher learning center - a University of a developing country Bangladesh. Berg and Lune (2012, p. 325) defines a case study method as 'an attempt to systematically investigate an event or a set of related events with the specific aim of describing and explaining these phenomena'. The crucial point of case study is a particular unit called the case. According to Willig (2001), a case can be an organization, a city, a group of people, a community, a patient, a school and others. While applying the case study method, researchers utilize different sub-methods like interviews, observations, documents and record analysis, work samples and others (Gillham, 2000). In this particular study, by taking into consideration the issue of confidentiality and anonymity, the case is simply to be known as the University. The networking pattern of different genders is the phenomenon that is currently investigated. This case study applies an in-depth interview as the sub-method. This University was selected as a case because this is one of the oldest and largest public universities of Bangladesh. It is also holds the most reputable quality in teaching and learning in the country.

The main objective of this study is to highlight the nature of social networking from a gender perspective. The specific objectives of this study are to:

\section{1. explore gender differences in social networking system; and}

2. ascertain whether social networking system is useful/beneficial at work.

This study is a qualitative study based on an in-depth interview method. The interviewees are the teaching staffs of the University. Both male and female teaching staffs (also called either teachers or faculty members) were interviewed. In total, twenty teaching staffs (ten male and ten female) were interviewed. The interviews were mostly tape recorded with the consent of the interviewees. In some cases where interviewees hesitated for tape recording, notes were taken. The interviews were transcribed and analyzed manually. The original names of the interviewees were not used in this article. Pseudonyms were mentioned. 


\section{The Theoretical Framework of the Study}

This study applies the social network theory. Social network theory is one of the relatively new and underdeveloped theoretical trends in sociology (Kurtosi, 2004; Ritzer \& Goodman, 2004). A social network deals with a limited set of actors and their relations (Kurtosi, 2004; Wasserman \& Faust, 1994). Rather than focusing only on the individual actors, network analysis concentrates on the features of the relationships among them. The actors in a network may be individuals, groups, corporations or societies. These actors may not have equal admittance to different resources like goods, services, wealth, power and information. According to Ritzer and Goodman (2004), social actors contribute each other with various resources and the asymmetrical allocation of different limited resources results in cooperation, contradiction and competition.

Over the last few years sociologists have shown immense interest in the 'gender based analysis of intra-organizational networks' (Kurtosi, 2004). According to Kurtosi (2004) human beings have a homophilic nature of relationship. This means that people want to make relationships with those who are similar to them. Generally people who tend to be part of a homophilic group have parallel characteristics in terms of sex, age, race, nationality or educational background. Same-sex friendship is a common phenomenon among human beings. It was found that, in organizations, men are more likely to keep informal relationships with men and women are more likely to have informal relationships with women (Brass, 1985).

The nature of relationship varies between male and female. Lever (1978) found that boys like to have bigger play-groups whereas girls prefer to have the company of only one friend rather than having groups. Girls look for intimate dyadic friendships. Moreover, in their social networks, women's information sharing is mainly related to family and relations, whereas, in a male network, the information sharing is more related to career, jobs and free-time activities (Smith-Lovin \& McPherson, 1985). It was also found that men can make use of informal interactions in a better way than women in getting promotions whereas women mostly depend on the formal structures in getting promoted (Henning \& Jardim, 1977).

From this discussion it can be said that the previous researchers have highlighted that the networking techniques differ between men and women. Men are more capable of utilizing their networks for the benefits of their careers. As mentioned earlier, this study sets its objectives on these issues.

\section{A Description of the Case - The University}

This study is based on a developing country - Bangladesh. This study concentrates on the workplace of education sector. The University was established in the early 1920s with three faculties and twelve departments consisting of sixty teachers in total. After the independence of Bangladesh (in 1971), the University was declared autonomous by the Government of Bangladesh. The University Order was published by the Government in 1973. In this order it is mentioned clearly that this University does not discriminate in relation to sex, religion, race, creed, class and color. This Order identifies total nineteen officer positions and among these some of the positions that the faculty members of the University can hold are: the Vice Chancellor, the Pro-Vice Chancellor, the Treasurer, the Deans, the Provosts and the Proctors.

From the informal discussions with the interviewees and some other persons in this University, it was found that networking (particularly political networks) plays an important role specifically in case of recruitment, promotion and getting strategic positions in the University administration. In order to understand this, a description of the real situation is needed.

The Vice Chancellor (VC), the Pro-Vice Chancellor (Pro-VC) and the Treasurer of the University are mainly appointed by the Chancellor of the University. The post of the Chancellor of the University is filled up by the President of the country. So, the people who will be appointed in these posts depend on the decision of the Government of the country. The Deans of the faculties are elected posts and they are elected through votes of all the faculty members of their respective faculties. Other than these officers, the University has some authorities like the Syndicate, the Senate, the Academic Council, the Finance Committee, the Selection Boards etc. A good number of positions in these authorities are held by the elected faculty members. So, social networks tremendously facilitate workers in securing these positions.

In comparison to other institutions, the University has a peculiarity in terms of appointing people in different strategic positions of these offices. It can be noticed that many of these posts are actually elected posts that are secured through direct voting of the faculty members of the University. The University makes all arrangements to make the election process successful. Social networking plays a vital role in getting the nominations as election candidates and winning in the elections. 
The selection of the candidates for the election is also unique in comparison to other organizations as well as somewhat political in nature. It is to be mentioned here that this University has a huge contribution in the political history of Bangladesh. Similarly, the students and the teachers of this University had immense contribution in solving different political crises of the country and the tradition still continues. Moreover, section 56(2) of the University Order 1973 states that the teachers and the officers of the University have the freedom to hold any kind of political views and get associated with any kind of legal organization and associations.

For this, it is seen that most of the faculty members of this University are somehow directly or indirectly involved with the political parties of Bangladesh. It should be mentioned here that there are mainly two big political parties in Bangladesh: The Bangladesh Awami League (BAL) and the Bangladesh Nationalist Party (BNP). Most of the citizens in Bangladesh mainly hold the ideologies of either of these two parties. Basing on these political ideologies, the faculty members of this University are also followers of either one of these two parties. There are mainly three political groups among the faculty members: the White group (following the ideologies of BNP), the Blue group (following the ideologies of BAL) and the Pink group (following the socialist ideology). These political groups play an important role during the time of elections for several posts for the teachers. In most of the cases these groups set their own panel of candidates who will compete in the election. Before election the candidates get time to convince the faculty members so that they vote for these candidates.

According to the opinions of the interviewees of this study, political alliance, in many cases, affects the decisions in relation to recruitment and promotion of the faculty members in this University. It has become a common tradition that the people in power will be helpful to those people of similar ideologies. During this study, through many informal conversations with the faculty members of this University it was noted that in many cases, political alliance become an important deciding factor on whether a person would be recruited in or promoted to a particular position. All these are dependent on a good networking with the people in different powerful authorities of the University.

But it was also found that manipulation in the recruitment and promotion process was not always easy as this University always gets a huge attention in the media. In the eyes of the print and electronic media, this is a very important educational institution of the country and any corruption will be made public when it is identified by the media. The researchers have also seen many newspaper reports related to manipulation in recruitment and promotion. But it has to be mentioned here that this institution is considered as the main think tank of the country. The students and the teachers have contributed immensely in almost all sectors of the country. It is considered as the most respected educational institution of the country because of its glorious history.

Another interesting tradition in case of recruitment is that though recruitment is done through open circular in newspapers available to all the citizens of the country, in general, there is an informal tradition that only the students who have passed from this particular University are to be recruited to their respective departments. Very few outsiders are recruited. In general, the top position holders in the merit list of the University examinations are hired as faculty members. It is a normal informal tradition that top position holders are recruited from each batch of students.

The next section of the article presents with the interview results of this study. The findings provide with an idea about how men and women strategize their networking in order to get benefits/opportunities from the relationships within the University.

\section{Findings and Analysis}

This section of the article presents with the findings of the study. It shows that, in this particular organization, men and women follow different strategies in creating and maintaining their networks. The relative importance of networking in the eyes of men and women is also different. The interviewees also mentioned that men can use their networks in a more efficient way in comparison to women.

The interviewees highlighted that men take the issue of networking more seriously than women. Almost all the interviewees irrespective of their sex mentioned that women's network is not as effective as that of the men. Maintaining good network requires meeting and making relationship with people. Most men can give time for that and most women cannot. The family responsibility and maintenance issues came as the causes of this.

For example, Abida Begum, a senior female Professor says that most of the male teachers meet each other in the University club at the evening. Going to the club is not a common practice among women as at evening they go home and take care of their children. So they do not get enough chance for 'socialization' and thus cannot build networks like men. According to her: 
"The club is a good place for 'socialization'. You will rarely see a female teacher visiting there and socializing with the colleagues. But you will find the male teachers even at ten o' clock at night-playing cards, tennis, chatting with the colleagues, having political discussions in the club. Women cannot do that. Moreover, it is also not safe for the women to stay outside at night. This is not a safe city. ... generally the club is opened at five in the evening. This is a very 'unsuitable time' for the female teachers as they have to take care of their families and children." [Female, Professor, Ex Chairman of a Department].

It is clear from the above interview excerpt that building network at the University is important, and one strategy is via 'socialization'. Yet it is not readily viable for women staff of the University.

\subsection{The Role of Network in Case of Recruitment and Promotion}

Informal networks came up as one of the important issues in the case of recruitment and promotion. Good informal networks with the colleagues and higher authority can be helpful in case of recruitment and promotion in this institution. This makes the process smoother and faster in many ways.

Moreover, in the case of recruitment and promotion, political networks and links are extremely relevant. In most of the cases, political inclination can make the recruitment and promotion process smoother for the candidates. It is described before that there are three political groups of the teachers of the University: the Pink group, the Blue group and the White group. From the informal conversations with the faculty members of this University and the responses of the interviewees, it was observed that the authorities generally prefer to recruit and give promotion to the people who are the supporters of their own groups. There is a clear rivalry among the groups and sometimes recruitment and promotion get delayed because of this rivalry. Due to this circumstance, many of the teachers of this University get involved in any of these political groups in order to be able to raise their voices when needed. Political groups can act as support when any discrimination happens to their members or supporters. Almost all of the interviewees agreed with the fact that women have poorer political networks in comparison to men.

According to a senior female Professor Rabeya Khan, recruitment and promotion are mainly 'politically biased' rather than 'gender biased' but as women are not good at maintaining political network, sometimes they suffer. Amir Ahmed, a male interviewee, commented that:

“... many of our recruitments and promotions are politically motivated and that is why these are influenced by informal political networks. Women suffer a lot in these cases. It is definitely true that women have poor professional and political networks. Another thing is, women's network mainly consists of women.... as there are less number of women in the powerful positions, women cannot use the informal networks in a fruitful way". [Male, Assistant Professor]

Razia Sultana, a female interviewee, also admitted that woman's networks mainly consist of women and these networks are 'nothing professional':

“...we talk about the schooling of our children, our husbands, housemaids or mother-in-laws (laugh) ... all these big issues !! (laugh) ... we deal with a lot of problems at our homes. All of us. I told you, for us, 'family comes first'. We have to accept so many things. We have to sacrifice a lot. We do not have many friends to share it. We need a 'window to pass the air'. That is why we talk about these issues". [Female, Lecturer, Newspaper Columnist]

Some of the interviewees highlighted that in recent years the young female teachers are trying to maintain networks. They try to contact the higher authorities and other important people before recruitment and promotion. Rozina Akter, a female interviewee, said that women prefer lobbying rather than networking. She highlighted that 'lobbying' and 'networking' are not the same:

"Lobbying and networking are not the same. I may lobby with some particular people for a particular purpose for some time but I cannot continuously keep relationship with them. I cannot manage time for that. So, my network always remains weak". [Female, Lecturer]

Razia Sultana said something similar:

“See, my promotion is due for 'almost one year'. I met my Chairman. I met some Syndicate members. Yesterday I met the newly appointed Pro-Vice Chancellor. I requested them to take necessary actions. Yes, I did that. But are they in my informal network? No, not at all. I met them just as a faculty member of this University. " [Female, Lecturer, Newspaper Columnist]

Abdur Rahman, a Professor and a member of the selection committee responsible for recruitment and promotion, commented that women are not good at lobbying also: 
"See, I really hate this tendency of lobbying. If you are eligible, you will get the promotion. There are specific criteria that you shall have to fulfill. If you have that you will get promoted. Even then people come to us for lobbying. I found that women are less capable of lobbying. In fact, I like that. When they come with a request, I find there is a 'sign of hesitation' on their faces... They are shy”. [Male, Professor, Member of the Selection Committee]

From informal discussions with some faculty members of the University, the researchers came to know that in this University, there are fixed rules regarding promotion. The faculty members have to serve for a fixed period and publish the specified amount of research papers in order to get promoted to the next higher rank. But even after fulfilling these requirements, there may be a need for using informal networks. The total processing of promotion needs time. In general, the applicants apply to the Registrar through the Departmental Chairman. Decision is taken in the Departmental meetings and then these applications are sent to the Registrar. After that the interview date is fixed. This total process takes time and in some cases because of political reasons, these processes get delayed. Good networks of the applicants help in fixing the interview date sooner and moving the files to different authorities faster. Men are in an advantageous position in this case as they have better informal networks.

Some interviewees highlighted the evidence of using of family networks (like the links of husband, father and other relatives) by women. For example, Rabiul Alam a male Lecturer mentioned a case where a Minister called the higher authorities of the University to recruit a female candidate as she was a relative to that Minister. This incident highlights the fact that women are not good at building and maintaining networks in the organizations. Because of this situation, they have to depend on personal relationships even to solve the problems of their professional lives.

But it was found that these days, women understand the importance of building and maintaining networks. Rozina Akter, a female lecturer finds the newly appointed female lecturers 'smart' as they try to build and maintain networks. Ahmedul Kabir, a male Associate Professor, commented that the situation is changing and these days many female faculty members are trying to build networks:

"In past, the female teachers used to have almost no network. This situation is not prevailing anymore. I found many recruits who built networks with the people in the authority long before their recruitment. I think, we should come out of this stereotyping of women. Things are changing”. [Male, Associate Professor]

From the findings it can be said that, in many cases, informal networks are proven to be helpful in making the recruitment and promotion process smoother and faster. Women are not good at socializing and building informal networks. Because of their devotion to the family affairs, they remain busy mostly outside their workplaces. So, in some cases, because of their poor networks, they suffer in the case of recruitment and promotion. But these days women are learning a lesson that network is important to do better in the job life. So, some of the new female recruits are giving importance in network building and maintaining.

\subsection{The Role of Political Network in the Professional Life}

Another important cause of women's poor networking is that women do not like politics. Moreover, because of their family responsibilities, they cannot invest time for building and maintaining political networks. As a result, in many cases, they are treated as politically irrelevant by men. Thus, they face problems in case of recruitment and promotion. Men are interested in politics. Women's participation in the politics is low. But politics (both organizational and national) plays a vital role in this University. The interviewees highlighted that though women's participation is increasing in the national politics of Bangladesh, still it is a general phenomenon that women dislike politics. As there is this general dislike towards politics from the part of the women, this dislike applies to organizational politics also.

Many of the interviewees highlighted the issue of women's participation in the national politics of Bangladesh. They said that these days many women are involved in the national parliament and showing satisfactory performance. For example, Razia Sultana, a female interviewee commented that:

"I must say women's participation in politics, these days, is very satisfactory. We have a good number of female leaders. Our Prime Minister, the main opposition party leader, home minister, foreign minister are women. Many female parliamentarians are there. They are doing well". [Female, Lecturer, Newspaper Columnist]

Additionally, Amir Ahmed, a male Assistant Professor also commented that women's participation in national politics is increasing: 
"I think in future this will have a great impact on the society and change the present status of women". [Male, Assistant Professor]

Furthermore, according to Ruhul Amin, a male interviewee said that some female parliament members are vocal, participative and 'very attacking to the opposition'. But when commenting on the politics of this University, Abida Begum, a senior female Professor and ex-Chairman of a department commented that, in general, women do not want to get involved in politics:

"...you will see that the participation of women in politics is low. ... I mean, in terms of number...by nature also women are softer and comparatively non-violent than men. You just see the things that happen in politics. You need to be loud and aggressive to deal with that. Women, by nature, are not likely to involve themselves in these situations. So, they generally stay away from politics". [Female, Professor, Ex-Chairman]

Rabeya Khan, another female Professor commented that though at the national level, there are some successful female politicians, women are not good in dealing with organizational politics. Especially in case of this University, women remain very reluctant about participating in politics. According to her, most women think politics as 'dirty game' that they do not want to play at all.

Hamidur Rahman, a male interviewee, who is working as a convener of a political group in a faculty commented that in this University, women are considered as 'politically irrelevant':

“.... I can just say that in this University women are considered 'politically irrelevant'. Yes, they have a tendency of not to get involved with politics. They do not have that time. So, their importance becomes less". [Male, Associate Professor, Convener of a political group of a Faculty]

It was also found that, because of their lack of interest in building and maintaining organizational and political networks, women fail to get the strategic positions of the University. In this University, there are some important strategic positions that are filled up by the faculty members/teachers/teaching staffs. Some of these positions are the Vice Chancellor, the Pro-Vice Chancellor, the Deans, the Treasurer, the Provosts (heads of the hostels), the Proctors and the Departmental Chairmen. Some other strategic positions are the Syndicate members and the Senate members.

Among these positions, there cannot be any gender discrimination in the case of the hostel Provosts as the male teachers get the posts of boys' hostels and the female teachers get the posts of girls' hostels. Also in the case of the Departmental Chairman, there cannot be any gender inequality as this post rotates on the basis of seniority. So, women naturally get these positions in a normal way.

On the contrary, the Vice Chancellor, the Pro-Vice Chancellor and the Treasurer are government appointed positions selected by the Chancellor - the President of the country. In almost hundred years of history of this University, twenty six Vice Chancellors were appointed, and none of them was female.

Up to 2012, fifteen Pro-Vice Chancellors have been appointed. Only two of them were female. There is no record of appointing any female Treasurer or Proctor.

The Deans of the faculty are mainly elected posts. Normally each political group will select their candidates for election. All the faculty members of a particular faculty will vote and thus the person who wins will be the Dean of that faculty. There are very few instances where female Deans were elected. At this moment there are thirteen faculties in the University and among them only few faculties like Law, Science, Biological Sciences, Engineering and Technology, Earth and Environmental Sciences and Fine Arts had few female Deans. Each of these faculties had the highest of two female Deans at different times. This number is very low in comparison to the number of the male Deans.

In the case of electing the Senate and the Syndicate members, according to the interviewees of this study, though the political groups nominate a few female members in the panel of candidates, the number is always too low in comparison to the males.

Most of the interviewees commented that it is not easy for the female faculty members to secure strategic positions and in many cases they are not even eager to take these positions. According to the interviewees, the main reason for not having women in the strategic position is that most of these positions are elected positions. As women do not involve much in the University politics and they do not have good networks like men, it becomes difficult for them to secure strategic positions. Moreover, huge family involvement makes them less interested to get strategic positions. Because of the stereotyped idea that women remain busy with their 
household affairs, many women do not get the nominations for election. According to the interviewees, these are the main reasons for which this University has been unable to have female leaders.

Nazneen Nahar commented that every year she sees at least one new male face in the election panel but the women members are almost the same over the years. She also commented that the male-female ratio in an election panel is also not satisfactory. In most of the cases, women's poor networking make them ineligible to get nomination in the elections:

"It is absolutely not easy to get strategic positions ...especially in the cases of the elected posts. They do not get much nominations also. In last three years I have found that in most of the cases, political groups nominated a very few number of female candidates...I have noticed one thing that the females who get nominations are always the same faces ... they get it because they have proved themselves so many times. You want to create new male leaders by disregarding women leadership". [Female, Lecturer]

It was also highlighted by a male interviewee Rabiul Alam that women face difficulties in election campaigning:

"Election campaigning is a difficult task for the women. In most of the cases they do not appeal for votes personally rather they come with the other nominated members of the panel... means, with other candidates. Men can go for more 'aggressive' campaigning. Women do not have much time to do all these things". [Male, Lecturer]

From the informal conversations with the faculty members the researchers came to know that an election is almost like an occasion in this University. After getting nominated from the political parties, the candidates get enough time for campaigning. In many cases they personally meet all the voters for this campaigning. Other than that they make telephone calls, send e-mails and SMS to contact the voters. This total process is time consuming and hectic. Women do not get enough time for these tasks as they have to maintain their families also. Another important fact that came up from the informal discussions of some teaching staffs of this University is that, as women are not interested to build and keep networks within the organization, it creates a barrier for them to appeal for votes in the election. Men, by creating and maintaining networks, can get close to the voters and can keep a continuing relationship over time. So, at the time of the election, appealing for votes become easier for them.

Mamata Akter, a female Professor who has twenty one years of work experience in this University, said that in many cases female faculty members are not prepared to take these positions. By 'prepared' she meant that one must be relatively free from family commitments before taking these positions. For example, if her children are grown up and her husband and other family members give her consent to take this position, only then a woman becomes prepared for taking a strategic position. Because of this family involvement, women cannot invest time for networking.

Because of their family commitments, women cannot give time to maintain these networks. So in some cases they suffer. Women's networks are mostly women oriented and not professional in nature. This finding supports the comments of Kurtosi (2004) and Brass (1985). They commented that same-sex relationship is a common matter and in organizations, men like to develop informal networks with men and women build informal networks with women. The findings of this study is also consistent with Smith-Lovin and McPherson (1985) where it was found that woman's information sharing is more related to family and relations. Henning and Jardim (1977) found that men can use informal network in a better way than women in case of getting promotion. This is also consistent with the findings of this study.

\section{Discussions and Conclusion}

The objective of this article was twofold: (1) explore gender differences in social networking system; and (2) ascertain whether social networking system is beneficial at work.

It was found from the study that the natures of social networking differ between men and women. It was also found that networking is beneficial for the success and survival in the organization. It was found in the study that in comparison to women, men emphasize more on networking. Men invest more time and energy to build and maintain networks. Women, for their family involvement and a general dislike towards politics, stay away from creating networks. Due to these circumstances, men get more advantage in comparison to women.

From this research it was found that though as a very old and established university of Bangladesh, this University has standardized rules and regulations for recruitment and promotion, in many cases, it is seen that informal network and political network make the processes of recruitment and promotion faster and smoother. In most of the cases these informal network are properly utilized by men only. Most of the men in this University invest a lot of time in maintaining personal and political links so that they can get benefited when needed. They 
can invest this time because in a patriarchal society of a developing country like Bangladesh, the responsibility of family care is mostly put upon the women and as a result men can emphasize more on their work life as their family remains under the care of the women. So it can be said that social norms and values play an important role on the creation and management of work life networks. Women have to meet the social expectations and that is why they give more importance on their roles as wives and mothers. Work gets a secondary importance in the lives of the working women. They become less visible in their works and thus their importance reduces. A stereotypical idea exists that women are more home-centric and that is why they are less available in their work life. For this, sometimes it is thought that women are not eligible for holding the strategic positions in the University as these positions demand huge time and energy from the position holders.

As women remain busy with their family affairs, in some cases, they lack the interest of having deep involvement with the work life. Because of the lack of interest in networking and politics, women sometimes get deprived from recruitment, promotion and getting strategic positions in the institution.

Though these days, some women recognize the importance of networking, the number is still low. Only new recruits are getting aware of this issue. In this research it was found that women sometimes use networks of personal/family relations in order to get some benefits. This approach of using the networks of others is also different from the network utilization by men. Men mostly use their professional and political networks.

Moreover, it was found that women's networking mostly revolves around women. The nature of this network is more personal than professional. It might help them in solving the problems of their personal lives but it cannot be helpful at a professional level. As men emphasize more on professional networking, they get many benefits from that. They use various political strategies including lobbying and campaigning to receive favor in their promotion. Yet these strategies are unlikely to be used among women at the University. It seems that the lack of political strategies further stall women's professional advancement. All these findings resemble with the findings of some previous studies (Bradley, 1999; Giscombe, 2007; Hussain, 2008; Jacobs \& Schain, 2009).

In the nutshell, both formal and informal networks are extremely important in the case of recruitment and promotion at the workplaces. Suitable formal networks iron out any obstacles in the process. At the same time, having good informal networks with the colleagues and higher authority accelerate the process further. Based on the current study, women suffer an obvious deficit in this case. They have limited strategies to attain social power and political networking for strategic positions at the University. Their limitations are both institutionalized and also personalized.

Though this research is a case study on a particular institution and the findings may not be generalized, it can be considered as an exploratory study in relations to gender and networking in the organizations/institutions of developing economies. Thus this study contributes in the literature on gender studies of the developing countries.

\section{References}

Berg, B. L., \& Lune, H. (2012). Qualitative Study Methods for the Social Sciences. Boston: Pearson.

Bradley, H. (1999). Gender \& Power in the Workplace: Analyzing the Impact of Economic Change. Great Britain: Macmillan Press Ltd.

Brass, D. J. (1985). Men's and women's networks: a study of interaction patterns and influence in an organization. Academy of Management Journal, 28(2), 327-343. http://dx.doi.org/10.2307/256204

Brown, R. (1976). Women as employees: some comments on study in industrial sociology. In D. L. Barker, \& S. Allen (Eds.), Dependence and Exploitation in Work and Marriage (pp. 21-40). London: Longman.

Crompton, R. (1997). Women \& Work in Modern Britain. NY: Oxford University Press.

Ferrante, J. (2011). Sociology a Global Perspective. Australia: Wadsworth Cengage Learning.

Gillham, B. (2000). Case Study Methods. London: Continuum.

Giscombe, K. (2007). Women in Corporate Leadership: Status and Prospects. In B. Kellerman, \& D. L. Rhode (Eds), Women and Leadership: The State of Play and Strategies for Change (pp. 383-403). San Francisco: Wiley.

Haas, B. (2005). The Work-Care balance: Is it possible to identify typologies for cross-national comparisons? Current Sociology, 53(3), 487-508. http://dx.doi.org/10.1177/0011392105051337

Hakim, C. (1996). Female Heterogeneity and the Polarisation of Women's Employment. NJ: Athlone.

Haralambos, M., \& Holborn, M. (2008). Sociology Themes and Perspectives (7th ed.). London: Collins. 
Heath, A. (1981). Social Mobility. Glasgow: Fontana.

Henning, M., \& Jardim, A. (1977). The Managerial Woman. New York: Anchor Press/Doubleday.

Henslin, J. M. (2006). Social Problems (7th ed.). New Jersey: Pearson Prentice Hall.

Hochschild, A. R. (2003). The Second Shift. England: Penguin Books.

Hunt, A. (1975). Management Attitude and Practices towards Women at Work. London: HMSO.

Hussain, I. (2008). Problems of Working Women in Karachi, Pakistan. UK: Cambridge Scholars Publishing.

Jacobs, P., \& Schain, L. (2009). Professional Women: The Continuing Struggle for Acceptance and Equality. Journal of Academic and Business Ethics, 1, 98-111.

Kendall, D. (2004). Social Problems in a Diverse Society (3rd ed.). Boston: Pearson.

Kessler, S. J., \& McKenna, W. (1978). Gender: An Ethnomethodological Approach. Chicago: Chicago University Press.

Knights, D., \& Morgan, G. (1990). Management Control in Sales Forces: A Case Study from the Labor Process of Life Insurance. Work, Employment and Society, 4(3), 360-389. http://dx.doi.org/10.1177/0950017090004 003004

Kurtosi, Z. (2004). Aspects of Gender in Social Network. In L. Czagany, \& L. Garai (Eds.), Social Identity, Information and Markets. Proceedings of Faculty of Economics and Business Administration. Szeged: JATEPress.

Lauer, R. H., \& Lauer, J. C. (2006). Social Problems and the Quality of Life (10th ed.). Boston: Mc-Graw Hill.

Lever, J. (1978). Sex Differences in the Complexity of Children's Play and Games. American Sociological Review, 43, 471-483. http://dx.doi.org/10.2307/2094773

Marchbank, J., \& Letherby, G. (2007). Introduction to Gender: Social Science Perspective. England: Pearson Longman.

Ramsay, K., \& Parker, M. (1992). Gender, bureaucracy and organizational culture. In M. Savage, \& A. Witz (Eds.), Gender and Bureaucracy (pp. 253-276). Oxford: Blackwell.

Ritzer, G., \& Goodman, D. J. (2004). Sociological Theory (6th ed.). Boston: McGraw-Hill.

Rohaiza, R. (2009). Women, work and Islam: A Malaysian experience. In H. A. Ibrahim, \& Z. Kamaruddin (Eds.), Muslim Women in Contemporary Societies: Reality and Opportunities (pp. 241-270). Malaysia: IIUM Press.

Rosaldo, M. Z. (1974). Women, culture and society: a theoretical view. In M. Z. Rosaldo, \& L. Lamphere (Eds.), Women, Culture and Society (pp. 17-42). Stanford, CA: Stanford University Press.

Smith-Lovin, L., \& McPherson, J. M. (1993). You are who you know: a network approach to gender. In P. England (Ed.), Theory on Gender/ Feminism on Theory (pp. 223-251). NY: Aldine de Gruyter.

Solovic, S. W. (2001). The Girls' Guide to Power and Success. New York: AMACOM.

Vogel, L. (1983). Marxism and oppression of women. NJ: Rutgers University Press.

Wasserman, S., \& Faust, K. (1994). Social Network Analysis: Methods and Applications. Cambridge: Cambridge University Press.

Wharton, A. S. (2005). The Sociology of Gender an Introduction to Theory and Study. UK: Blackwell Publishing.

Willig, C. (2001). Introducing Qualitative Study in Psychology. Buckingham: Open University Press.

\section{Copyrights}

Copyright for this article is retained by the author(s), with first publication rights granted to the journal.

This is an open-access article distributed under the terms and conditions of the Creative Commons Attribution license (http://creativecommons.org/licenses/by/3.0/). 